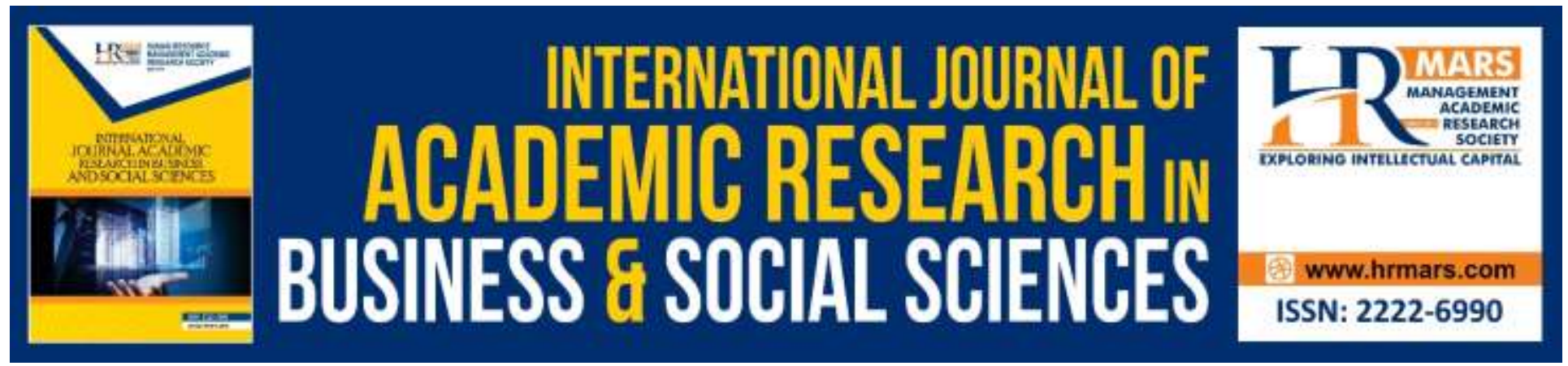

\title{
Predictors of Skills Acquisition among Students with Learning Disability in Agricultural Science Subject
}

\author{
Umar, M. A., and Rashid, A. M.
}

To Link this Article: http://dx.doi.org/10.6007/IJARBSS/v9-i10/6493

DOI: 10.6007/IJARBSS/v9-i10/6493

Received: 10 Sept 2019, Revised: 30 Sept 2019, Accepted: 05 Oct 2019

Published Online: 30 Oct 2019

In-Text Citation: (Umar \& Rashid, 2019)

To Cite this Article: Umar, M. A., \& Rashid, A. M. (2019). Predictors of Skills Acquisition among Students with Learning Disability in Agricultural Science Subject. International Journal of Academic in Research Business and Social Sciences, 9(10), 301-314.

Copyright: (C) 2019 The Author(s)

Published by Human Resource Management Academic Research Society (www.hrmars.com)

This article is published under the Creative Commons Attribution (CC BY 4.0) license. Anyone may reproduce, distribute, translate and create derivative works of this article (for both commercial and non-commercial purposes), subject to full attribution to the original publication and authors. The full terms of this license may be seen

at: http://creativecommons.org/licences/by/4.0/legalcode

Vol. 9, No. 10, 2019, Pg. 301 - 314

http://hrmars.com/index.php/pages/detail/IJARBSS

JOURNAL HOMEPAGE

Full Terms \& Conditions of access and use can be found at http://hrmars.com/index.php/pages/detail/publication-ethics 


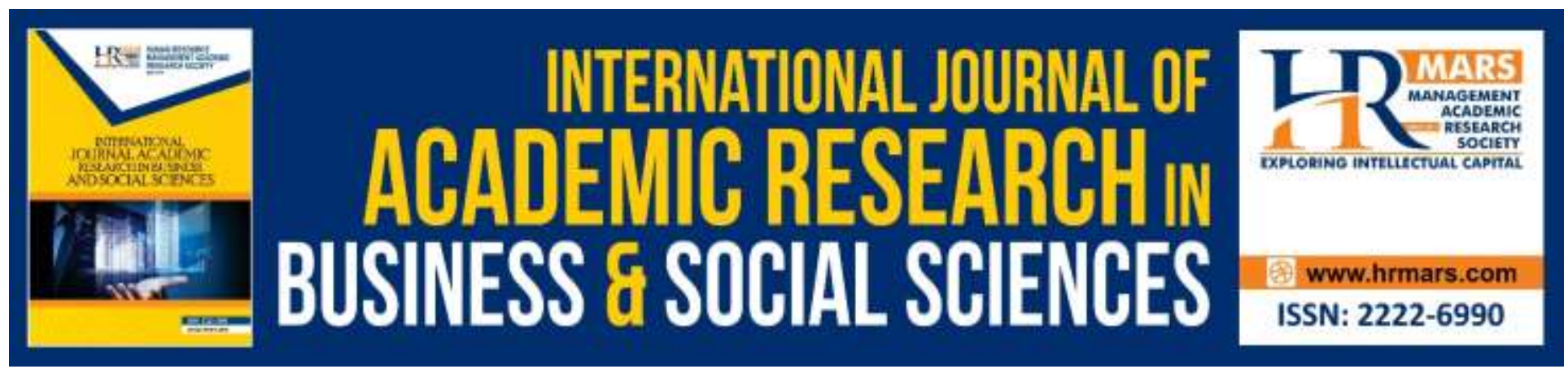

\title{
Predictors of Skills Acquisition among Students with Learning Disability in Agricultural Science Subject
}

\author{
Umar, M. A., and Rashid, A. M. \\ Faculty of Educational Studies, Univesiti Putra Malaysia
}

\begin{abstract}
In inclusive education principals' competence, parent involvement and availability of infrastructure were viewed among the contributing factors that determines the effectiveness of secondary schools. Despite their important in the area, there was less substantial study regarding to these predictors in Adamawa state secondary schools. The aim of this study is to identify the predictor in the implementation of inclusive education on skills acquisition among students with learning disability in agricultural science subject. Therefore, the study investigated how the agricultural science teachers perceived the most predicting variable among the predictors in the implementation of inclusive education in Adamawa state secondary schools, Nigeria. The study employed a cross-sectional survey design with multi-stage cluster sampling technique. A validated survey instrument was distributed to 243 agriculture teachers in Nigeria that were asked about their perception on the selected factors in implementing inclusive education on skills acquisition among students with learning disability in agricultural science subject. The analysis of the data revealed that all the variables significantly predicted skill acquisition among students with learning disability in agricultural science subject, however; parent involvement appeared to be the leading predictor with $(\beta=.397, \mathrm{P}=.000$ ). Therefore, in other to improve on the other predictors in Adamawa state secondary schools; it is essential to emanate an extensive, organized and rational program for improving their predicting effects by looking at the items that measured it in the questionnaire, thus may improve the level of effective implementation of inclusive education in Adamawa state secondary schools.
\end{abstract}

Keywords: Inclusive Education, Technical and Vocational Education and Training (Tvet), Principals' Competence, Parent Involvement, Infrastructure Availability

\section{Introduction}

Education for All (EFA) which stands for international committee to make sure that everyone (children and adults) irrespective of whether disabled or non-disabled receives basic education. This is based on both human rights and the general belief that, education is central to individual 
well-being and the development of any nation. According to Ogbueghu and Ugwu (2016) for education to be for all, it must be received by all. However, current evidence by Hopkins (2015) suggests that, proper attention has not been given to some marginalized children and adults most especially those that are require special need education. Those systems that exclude some people cannot be for all and therefore must give a chance to those that are ready to accommodate all. This means that, any system that serves only specific groups of children or adults, while denying attention to others who are seriously in need of assistance, does not deserve any consideration in the 21st century. Therefore, technical and vocational education and training (TVET) is a part of the inclusive education strand of the Commonwealth which make sure that the education children and adult's needs are met through equal access to suitable programme in learning and life-skills (Okoye, Arimonu \& Ogwo, 2018).

Training of skilled manpower is the major concern of TVET as an aspect of education. According to Ogbuanya and Okoli (2015), it is an aspect of education which is focused mainly towards preparing people to become productive in a paid employment or self-employment. However, the development of skills that is practical in nature is the main thrust of TVET. A well functional workshop that is fully equipped with relevant facilities and equipment is a suitable environment where the acquisition of relevant skills of construction, designing and repairing can take place. This is to make sure that quality, dependable and sustainable employable skills are given to the learners. In order to achieve high quality education for the world of work in the context postconflict of education for EFA, Galguera (2016) stressed that, the UNESCO-UNEVOC is placed to provide technical assistance to developing countries, countries in transition and those in TVET is interlocked with the acquisition of skills and hence sustainable employability. Exposing people to skills training raises hope for useful livelihood. The UNESCO member states identified TVET and skill acquisition for employability and sustainable livelihood as a major and growing priority of its range program of activities (Dania, Bakar \& Mohamed, 2014).

TVET access is a delicate problem for disabled individuals. Segregated TVET settings are still fou nd in many countries where inclusive education has been introduced with little choice for learn ers with special needs education (Najoki, 2014).

It has been recognized that inclusive education is a strategy that accommodates learner diversity and in turn curbs marginalization (Clark, 1995). It includes the philosophy that guarantees that schools, centers and instructional systems are accessible to all learners (skilled and disabled). Numerous research has shown that inclusive education involves the identification and removal of obstacles within and around the school that may hinder education for all (Garuba, 2015; Armstrong, Armstrong \& Barton, 2016; Boit, 2016; Gargiulo \& Metcalf, 2017; Gavish, 2017).

Despite the benefits of inclusive education, gaps are obvious in its implementation in Adamawa State, Nigeria. In most Adamawa State secondary schools, there is a lack of commitment to inclusive education practices (Post Primary Schools Management Board, 2016). Research conducted previously in Nigeria addressed critical issues related to the implementation of the Universal Basic Education Program (UBE) in Nigeria, while ignoring the leading predictors in the 
implementation of inclusive education in secondary schools (Ejere, 2016). The purpose of this study is to identify the leading predictor (principals' competence, teachers' competence, parents' involvement, availability of infrastructures) in the implementation of inclusive education on skills acquisition among students with learning disability in agricultural science subjects.

\section{Theoretical Framework}

The psycho-productive domain model of Ezewu (1985) have contributed to this study's theoretical structure. The researcher also used the perspective of the psycho-productive domain model as there are some ideas that learners with special needs may have issues adjusting to new settings such as being an inclusive classroom in the implementation of inclusive education. The psycho-productive domain model assumes that it can be routine and even automatic under certain circumstances to learn qualified behaviors. The psycho-productive domain is thought to be not just a skill development theory, but a general learning theory ranging from cognitive to psychomotor abilities. The essence of these frameworks is always to provide an awareness of the impact of environmental processes in human development and to outline the duties of the school, parents, society and government in contributing to the provision of life-long learning to bring about the personal development of all learners.

The psycho-productive domain model of Ezewu (1985) would be appropriate for technical and vocational education and training (TVET) skill acquisition reasons. This is because Ezewu rightly noted that there are many elements in the nature of TVET involving training both in theory and in practice. Furthermore, the theory acts as the basis for studying the practical skills in these parts. Thus the theory is put at the reduced stage in Ezewu's model, whereas the practical is positioned at the greater stage of the subject's knowledge. Moreover, behavioral modifications are so patterned in a linear order that before the learner receives a knowledge of the procedure of the greater level in TVET he / she must have first learned the fundamental values or steps.

A critical examination of the model of Ezewu would reveal that it is educationally based. This model involves all the taxonomies and thus involves the three skill elements. The model took care of Padelford's (1988) observation that acquiring and developing skills are learning operations that involve not only the psychomotor, but also the affective and cognitive domain. Garba (1993) regarded Ezewu's model as a remedy in an attempt to provide a means of evaluating the psychomotor result of technical and vocational education and training programs among learners. This is because Ezewu has stated that the proposed classification is tentative and only curriculum planners and educators can determine its applicability and usability through exercise in associated areas. Garba (1994) attempted Ezewu's model to develop a tool to evaluate practical ability acquisition in TVET classrooms. According to him, it was discovered worthwhile.

This means that the development of abilities in inclusive education among students with learning disabilities in agricultural science depends largely on the kinds of abilities taught to the learners, methods or transmission techniques, assessment techniques used to evaluate the learners, and the accessibility of equipment to teach the learners the abilities. The skill was clarified by 
Martinez-Martinez-Fernandez and Choi (2013). Olaitan (1996) said the need to develop gained abilities in vocational work is necessary as one may possess a skill but the abilities are not created. Olaitan further explained that it is necessary to teach understanding and competencies in the course of obtaining skills in an occupation needed for achievement in that occupation. This is because skills consist of habits that need to be adapted. Skill development theory is therefore important to this research.

\begin{tabular}{|c|c|}
\hline Levels & Direction \\
\hline 1. Low level & $\begin{array}{l}\text { Understanding of: } \\
\begin{aligned}- & \text { Terminology } \\
- & \text { Scope of job or task } \\
- & \text { Job specification } \\
- & \text { Instructions and materials }\end{aligned}\end{array}$ \\
\hline $\begin{array}{l}\text { 2. Middle } \\
\text { level }\end{array}$ & $\begin{array}{l}\text { Task identification: } \\
\text { - Identifies task in a job and } \\
\text { - } \text { Break jobs into tasks } \\
\text { Task element specification: } \\
\text { - Identification of task elements } \\
\text { - } \text { Break tasks into elements } \\
\text { - } \quad \text { Select appropriate materials and instruments }\end{array}$ \\
\hline 3. High level & $\begin{array}{l}\text { Execution: } \\
\text { - } \text { Willingness to execute } \\
\text { - } \text { Handles materials and instruments } \\
\text { - } \text { Properly execute with required speed } \\
\text { - } \quad \text { Execute according to specification } \\
\text { - } \quad \text { Cooperate with necessary orders } \\
\text { - } \quad \text { perseveres }\end{array}$ \\
\hline
\end{tabular}

Figure 1: Psycho-productive domain model (Ezewu, 1985)

\section{Research Methodology \\ Participants}

It has been determined that agriculture teachers are among those most probable to have important contact in inclusive school environments with students with LD. The respondents in this research were approached directly to see if they were interested in answering the questionnaire of the survey. The target research population included all of the current secondary school agriculture teachers in Adamawa Sate. According to Post Primary Schools Management Board, Yola, there are two hundred and forty seven $(\mathrm{N}=247)$ agriculture teachers serving in Adamawa State secondary schools at the time of the study in 2018. Because of the limited size 
of the target population, a sampling procedure was not involved in the study. Instead, all agriculture teachers were given a survey instrument. The research included all five education zones in the study state. Agricultural science teachers were primarily males for the five education zones and similar in terms of their average age and number of years of teaching.

\subsection{Recruitment and Data Collection Procedures}

This study was conducted in accordance with the ethical norms suggested by Adamawa State, Nigeria, Post Primary Schools Management Board. Within zone one that were contacted in the study area, a number representing the area's colleges were chosen. The exception was in Zone 3 and 5, inviting all schools to participate in the studies. Then the principal of each selected school was approached within each educational zone and provided with the study's main goals and parameters, requesting that he or she to participate in the study. To have a representative sample of teachers, the study developed the criterion for considering the school only if all agricultural teachers agreed to complete the questionnaire. The answers from the respondents remained anonymous. Questionnaires have been distributed and presented in paper form within a school. A research assistant who could distribute a paper version of the questionnaire and who would answer questions or concerns about study processes was hired in each education zone.

\subsection{Questionnaire}

In this study, the research instruments used is questionnaire divided into seven sections ( $A$ to $E$ ). Section ' $A$ ' relates to the demographic information of the respondents. Sections $B$ to $F$ of the questionnaire were developed by the researchers. Section ' $B$ ' contained a questionnaire on principal's competence in implementing inclusive education of students with disabilities in the agricultural science subject. Section ' $C$ ' contained a questionnaire on the role of infrastructural facilities in implementing Inclusive education. Section ' $D$ ' contained a questionnaire on Parents Involvement in Secondary School Education. Section ' $E$ ' on the other hand contained skills acquisition of students with disabilities in the agricultural science subject. In total, all the constructs in sections ' $\mathrm{B}$ ' to ' $\mathrm{E}$ ' were measured by a total of 123 items.

\section{Results}

\section{The Leading Predictor of Skill Acquisition among Students with Disabilities in implementing inclusive education}

The objective of this study is to examine the leading predictor of skill acquisition among students with disability in agricultural science subjects. Therefore, to determine the extent of the prediction of each of the variable, multiple regressions analysis was conducted and it was explained by the Beta value $(\beta)$, Regression model consists of three predicting variables, namely; Principals' Competence $\left(\chi_{1}\right)$, Parent Involvement $\left(\chi_{2}\right)$, Availability of Infrastructure $\left(\chi_{3}\right)$. Prediction equation is express below:

$\hat{Y}=b_{0}+b_{1} \chi_{1}+b_{2} \chi_{2}+b_{3} \chi_{3}++e_{i}$

Where:

$\hat{Y}=$ Skill Acquisition among Students with Learning Disability; 
$\chi_{1}=$ Principals' Competence;

$\chi_{2}=$ Parent Involvement;

$\chi_{3}=$ Availability of Infrastructure;

$\varepsilon=$ Random error.

Skill acquisition $=\beta_{0}$ constant $+\beta_{1}($ Principals' competence $)+\beta_{3}$ (Availability of Infrastructures $)+$ $\beta_{4}$ (Parents'involvement $)+\varepsilon_{i}$ Random error

Table 1. Model Summary ^b

\begin{tabular}{llllll}
\hline \hline Model & $\mathrm{R}$ & $\mathrm{R}$ Square & Adjusted R Square & \multicolumn{2}{c}{ Std. Error of the Estimate } \\
1 & $.716^{a}$ & .512 & .506 & .57996 & \\
\hline \hline a. Predictor: & (Constant), & Principals' & Competence, & Parent & Involvement, Availability of \\
Infrastructure & & & & \\
b. Dependent Variable: School effectiveness & & &
\end{tabular}

The result produced by utilization the SPSS V22 software in Table 1 indicated the value of $R$ square and Adjusted $\mathrm{R}$ square (.512 and .506) respectively. This showed that, about $50 \%$ of variance in skills acquisition among students with learning disability is explained by the predictor variables (Principals' Competence, Parent Involvement, and Availability of Infrastructure).

In order to test for the leading predictor of the skills acquired among students with learning disability, the predictors; principals' competence, availability of infrastructures and parents' involvement in the regression model, standard multiple regression were employed. The preliminary assumption testing for normality, linearity, multicolinearity and homoscedasticity proved no violation of the basic assumptions. Thus, the summary result indicated that, the regression model is significant $(F(4,291)=96.726 ; p=.000)$. Moreover, the analysis showed that about $57 \%$ of variance in skill acquisition among students with disability was explained by the predictor variables entered into the regression model.

Table 2. Results of Multiple Regression Analysis among Variables of the Study

\begin{tabular}{lccccc}
\hline Variables & B & S.E & $\boldsymbol{B}$ & $\boldsymbol{t}$ & $\boldsymbol{p}$ \\
(Constant) & 4.823 & 1.654 & & 2.916 & .004 \\
Principals' Competence & .209 & .072 & .218 & 2.899 & .004 \\
Parents' Involvement & .416 & .071 & .397 & 5.875 & .000 \\
Availability of Infrastructures & .220 & .049 & .253 & 4.509 & .000 \\
\hline
\end{tabular}

$\mathrm{R}^{2}=.571 ;$ Adjusted $\mathrm{R}^{2}=.565 ; \mathrm{F}(4,291)=96.726 ; \mathrm{p}<.05$

Note: $B=$ Unstandardized Coefficients; $S E=$ Standard Error; $\beta=$ Standardized Coefficients.

The regression analysis in Table 2 shows a significant relationship between parents' involvement and skill acquisition among students with disabilities in the agricultural science subject $(\theta=.397$, $t=5.875, \mathrm{p}<.05)$. The regression equation indicated that for every unit of increase in parent involvements, skills acquisition rate is increased by.416 units. This confirms that parents' 
involvement significantly predicts skill acquisition among students with disabilities in the agricultural science subject. Furthermore, the results in Table 2 have revealed that there is a significant relationship between availability of infrastructure and skill acquisition among students with disabilities in the agricultural science subject $(B=.253, t=4.509, p<05)$. The regression equation indicated that for every unit of increase in availability of infrastructure, skills acquisition rate is increased by.220 units. This depicts that availability of infrastructural facilities significantly contributes to skill acquisition among students with learning disabilities in the agricultural science subject.

Moreover, the results in Table 2 have shown that a significant relationship between principals' competence and skill acquisition among students with disabilities in the agricultural science subject $(b=.218, t=2.899, p<.05)$. The regression equation indicated that for every unit of increase in principals' competence, skills acquisition rate is increased by. 209 units. Therefore, it can be established that all the variables of the study; principals' competence, parents' involvement and availability of infrastructure significantly predicts skill acquisition among students with learning disability in agricultural science subjects. However, parent involvement is having the highest beta value of.397, which indicated highest significant contribution to skills acquisition among students with learning disabilities compared to principals' competence and availability of infrastructure. Therefore, parent involvements emerged as the best predictor of skill acquisition among students with disabilities in the agricultural science subject.

This can be explained by the fact that, an increase in parents' involvement could lead to more skills acquisition than when there is an increase in principals' competence and availability of infrastructure. For example, a $1 \%$ increase in parents' involvement will trigger a $0.397 \%$ or if there is an increase in parents' involvement by $10 \%$, will explosively trigger a $30.97 \%$ increase in skills acquisition respectively. On the other hand, if there is an increase in principals' competence for example by $1 \%$, will attract a $0.218 \%$ increase in skills acquisition. This value $(0.218)$ is relatively lower than 0.397 which is the value of parents' involvement. Furthermore, availability of infrastructure also yields a coefficient value of 0.253 less than that of parents' involvement.

\section{Discussions of Research Findings}

The following discussion about principals' competence, parent involvement and availability of infrastructure are important factors for effective implementation of inclusive education especially with the increasing number of students with learning disabilities.

\section{Predictors of Skill Acquisition among Students with Learning Disability}

Findings of this study established that all the variables of the study; principals' competence, parent involvement and availability of infrastructure significantly predicts skills acquisition among students with learning disability in agricultural science subject. This was obtained when all the entire items of these variables were measured.

However, parents' involvement appeared to be the leading predictor of skill acquisition among students with learning disabilities in agricultural science subject. By validating the predictive role of parents' involvement towards attainment of skills acquisition of students with learning disabilities, this study provides an understanding on the vital role parents' involvement has in 
skill acquisition. However, there was no research found that focused on the predicting roles of factors such as principals' competence, availability of infrastructure and parents' involvement on skill acquisition among students with learning disabilities in agricultural science subject concurrently. Most of the study conducted in TVET does not adequately captured these variables been used in this study. But there are some researches that were conducted to study the relationship between these variables and students' academic performance (Naz, Khan, Daraz, Hussain, Alam \& Alam, 2012; Gistituati \& Suyuthie, 2018; Seng, Hanafi and Taslikhan 2016; Fajoju, Aluede \& Ojugo 2016).

Result of Fajoju, Aluede and Ojugo (2016) research stated that parental involvement considerably affected academic achievements of students in three key topics, English Language, Mathematics and Integrated Science, in primary school, and that the greater the participation of parents, the greater the achievement of students in the three key topics. In a related study, Seng, Hanafi and Taslikhan (2016) concluded that there is a significant influence of parental involvement on children's academic achievement. This implies that, parental involvement in the form of relationship with the child associated with good academic achievements give encouragement and incentives that can affect the students' interest in their studies. Furthermore, parents always communicate with children can make children feel appreciated and this feeling leads children to do their best to appreciate their parents.

Despite no empirical studies found that studied the predictive ability of the study variables on skills acquisition among students with learning disabilities, it appears from the few existing related researches that parents' involvement occupies an important position in skills acquisition among students with learning disabilities. Results of this study showed that parent involvement is the leading predictor of skills acquisition among students with learning disability in agricultural science subject. Therefore, it can be concluded that all the variables should be considered as critical predictors of skills acquisition among students with learning disability in agricultural science subject. However, much emphasis should be given to parent involvement being it as the leading predictor of skills acquisition among students with learning disability in agricultural science subject.

\section{Conclusion}

Based on the finding of this study, it is evidenced that the relationship between principals' competence, parent involvement and availability of infrastructure with skills acquisition among students with learning disability in agricultural science subject was positively significant. In view of this finding, it is desirable that, enabling environment be created by principals, educators, parents, and management of institutions for students in an inclusive school settings to improve their skills acquisition before transit from school to the competitive labor market. School principals' competence is an essential factor in implementing inclusive education.

Principals' competence for inclusive education contributes immensely to the acquisition of skills, knowledge and support teachers to effectively teach the students. This factor can contribute strongly towards successful implementation of inclusive education on skills acquisition among students with learning disability in agricultural science subject. In addition, the competent principals should be able to utilize their skills and knowledge to motivate teachers prepare 
teaching/learning materials for students with learning disabilities using locally available materials. Therefore, the principals ought to have very high level of competence so that they could be acquainted with learning disability issues in implementing inclusive education.

Availability of infrastructure and other learning materials suitable to the needs of all students are necessary in an inclusive education setting. This would enable the teachers to teach and all students to learn effectively. It was evident that the schools had strived to adapt the physical environment to make it accessible and more conducive for learning. For continued provision of appropriate infrastructure for students with learning disability to learn effectively, financial support is also very necessary. Without financial support to the schools, then it would be difficult for the school management and the parents alone to provide and maintain the available infrastructures required for the students with learning disability as the need may arise. Saari and Rashid (2013) suggested the cooperative vocational education that involve educational institution and industry partner will strengthen the quality of workforce. They found that multinational companies always make sure their trainee undergo a training program to enhance their skills during the training as the companies provided expertise and latest technology. For successful implementation of inclusive education therefore there is also the need for parent's involvement as well can implementing cooperative vocational education in order to maintain the available infrastructure in the school.

Parent involvement has been a subject of interest for many years in the education of learners with learning disabilities. While study by Amponsah, Milledzi, Ampofo, and Gyambrah (2018) and Wilder (2014) argues that parental involvement has a beneficial impact on academic achievement in standard classrooms among learners with learning disabilities. There is still concern about what constitutes parental involvement in the development of abilities in agricultural science subjects among learners with learning disabilities. As demonstrated throughout this research, parental involvement through cooperation with teachers, community, and students is crucial to the academic achievement of the student. By researching the views of agricultural science teachers on parental participation, a stronger, more unified strategy may emerge on ways to enhance parental participation and assist families, educators, and community members to work together to foster student achievement in acquiring skills in agricultural science. Overall findings of the study showed that the success of inclusive education sorely depends on principals' competence, availability of availability of infrastructure and parents' involvement to be addressed in the implementation of inclusive education in the study area.

\section{Theoretical Implications}

Although, there are no studies found on the relationship between principals' competence, availability of infrastructure and parents' involvement with skill acquisition among students with learning disabilities, few studies were found on the relationship between these variables and students' academic achievement. The present study contributed for the first time in exploring the relationship between principals' competence, parent involvement and availability of infrastructure with skills acquisition among students with learning disability in agricultural science subject concurrently. Furthermore, the established positive and significant relationships among the variables that will provide a support for the psycho-productive domain model skills 
because, the results of this study indicates how these variables (principals' competence, parent involvement and availability of infrastructure) can contribute as input in skills acquisition among students with LD in agricultural science subject as output.

Another contribution of this research to the literature is that, it proposed a model on skills acquisition among students with learning disability in agricultural science subject. This proposed model can be used in order to enhance a better understanding of skills acquisition among students with learning disabilities in agricultural science subject.

In conclusion, despite the fact that various researches exist as regards to the relationship between principals' competence, availability of infrastructure with students' academic achievement, no similar research has been found to show the relationship among these variables concurrently and at the same time identifying the leading predictor of skills acquisition among students with learning disabilities in TVET subject area and specifically in agricultural science in Nigeria. Therefore, this study is a unique in TVET educational settings to set a new track for upcoming researches in relation to the contributions of principals' competence, availability of infrastructure and parents' involvement towards the realization of skills acquisition among students with learning disabilities.

\section{Implications to Practice}

The findings of this research have some implications to practitioners. It serves as a source of empirical evidence to the policy makers and teachers on the level and the extent of relationship between principals' competence, availability of infrastructure, parents' involvement and skills acquisition among students with learning disabilities in secondary schools in Adamawa State, Nigeria. Prior to this research, there is lack of empirical and theoretical evidence in relation to the research variables in TVET area and this can lead to ambiguity and doubt among the policy makers and practitioners to put the variables into use within the context of inclusive education. Majority of past researches focused on academic achievement of students with learning disabilities in general subjects. However, this study adopted and studied variables that include principals' competence, availability of infrastructure and parents' involvement in TVET and found them to be instrumental to skills acquisition among students with learning disabilities. Hence, the ministry of education can adopt and set modalities to encourage skills acquisition among students with learning disabilities in TVET.

The findings of this study which depicts that principals' competence is significantly related to skills acquisition among students with learning disabilities also may clears the doubt among policy makers that principals' competence is only applicable in the mainstream or general school settings. Therefore, this research evidently provides justification to practitioners that the application of principals' competence as factor is also applicable for attainment of inclusive education goals and objectives.

Moreover, the results of the study have shown that parents' involvement is the best predictor of skill acquisition among students with learning disabilities in agricultural science subject which shows the need for policy makers to improve and strengthen parental involvement for the overall inclusive education program. 
Furthermore, it will provide a practical roadmap for the development of skill acquisition in the context of technical and vocational education and training. Also, the questionnaires for this study can be considered as vital measuring instrument to help educational leaders and policy makers diagnose the weaknesses and strengths of inclusive education schools.

\section{Recommendation Based on the Findings}

Findings of this study offered practical recommendation for the ministry of education, policy makers, school principals and teachers about the link between principals' competence, availability of infrastructure, parents' involvement and how they could foster the implementation of inclusive education on skills acquisition among students with learning disabilities in Adamawa State, Nigeria.

The findings of this study have identified parents' involvement in implementing inclusive education as the best predictor of skill acquisition among students with learning disabilities in agricultural science subject. This underscore the need for policy makers and school principals to emphasize on different forms of parental involvement with a view of achieving the goals and objectives for effective implementation of inclusive education.

\section{Recommendation for Future Research}

This study provided the ground for future studies to increase the understanding of the relationship between principals' competence, availability of infrastructure and parents' involvement with skills acquisition among students with learning disabilities in agricultural science subject. In addition, this study is important because the concept of skills acquisition was examined in the context of inclusive education for the first time in Adamawa State, Nigeria. Based on the results and conclusions of this study, a number of recommendations for future researches were offered. The recommendations are as follows:

1. The population of this study is limited to agricultural science teachers in Adamawa State, Nigeria. Therefore, a similar research can be conducted in other states of Nigeria. Furthermore, future researches should include other stakeholders such as the school principals and parents as respondents.

2. The study adopted measures that were originally design to assess such variables in general education settings. Although, the measures adopted were further exposed to content validation to justify their use, there is the need for developing measuring instruments that are mainly for inclusive education and TVET subjects like agricultural science. Therefore, future researchers should consider developing instruments for measuring principals' competence, availability of infrastructure, parents' involvement and skills acquisition among students with learning disabilities that would meet the needs of inclusive education school settings.

3. The study used demographic information of the respondents only for descriptive purposes. Therefore, future studies should look into the possibility of using demographic variables to examine the differences in the levels of principals' competence, availability of infrastructure and parents' involvement in inclusive education based on teachers' perspectives. 
4. This study was based on self-reporting data. Thus, in order to minimize the limitation of self-reporting data, further study is required to adopt a qualitative research technique.

5. This study used demographic variables only for description purpose. Therefore, future studies should look in to the possibility of using demographic variables such as gender, age, qualification and experience to examine the differences in the levels of principals' competence, availability of infrastructure and parents' involvement with skills acquisition among students with learning disability in agricultural science subject.

\section{Corresponding Author}

Abdullah Mat Rashid is associate professor at the Faculty of Educational Studies, Universiti Putra Malaysia, 43400 UPM Serdang, Selangor Darul Ehsan, Malaysia.

Email: abmr@upm.edu.my

\section{References}

Amponsah, M. O., Milledzi, E. Y., Ampofo, E. T., \& Gyambrah, M. (2018). The relationship between Parental Involvement and Academic Performance of Senior High School Students: The Case of Ashanti Mampong Municipality of Ghana. American Journal of Educational Research, 6(1), 1-8.

Armstrong, F., Armstrong, D., \& Barton, L. (2016). Inclusive education: Policy, contexts and comparative perspectives. New York: Routledge.

Boit, C. J., Ikiara, G., Odhiambo, A. E., Tuda, R. A., Mung'atia, J., \& Chengecha, A. M. (2016). Extent of success in implementation of inclusion of special needs children's access and participation in preschools in Kericho County. (Doctoral dissertation, University of Nairobi) (Kenya).

Clark, C. (Ed.), Dyson, A. (Ed.), Millward, A. (Ed.). (1995). Towards Inclusive Schools? London:

Routledge, https://doi.org/10.4324/9780429469084

Dania, J., Bakar, A. R., \& Mohamed, S. (2014). Factors Influencing the Acquisition of Employability Skills by Students of Selected Technical Secondary School in Malaysia. International Education Studies, 7(2), 117-124.

Ejere, E. I. (2011). An Examination of Critical Problems Associated with the Implementation of the Universal Basic Education (UBE) Programme in Nigeria. International Education Studies, 4(1), 221-229.

Ezewu, E. E. (1985). Sociological Ideas and Educational Practice. RAl Obanga, M. Okoye, Ezewu, E. and D. Ajejumo, (1985). Theory and Practice of Education. Lagos: Basic Books Publishers.

Fajoju, S. A., Aluede, O., \& Ojugo, A. I. (2016). Parental involvement as a correlate of academic achievement of primary school pupils in Edo State, Nigeria. Research in Education, 95(1), 3343.

Gargiulo, R. M., Metcalf, D., \& Metcalf, D. J. (2017). Teaching in Todays Inclusive Classrooms: A Universal Design for Learning Approach: Nelson Education. Third Edition. Australia: Wadsworth.

Garuba, A. (2003). Inclusive Education in the 21st Century: Challenges and Opportunities for Nigeria. Asia Pacific Disability Rehabilitation Journal, 14(3), 191-200. 
INTERNATIONAL JOURNAL OF ACADEMIC RESEARCH IN BUSINESS AND SOCIAL SCIENCES

Vol. 9, No. 10, October, 2019, E-ISSN: 2222-6990 @ 2019 HRMARS

Gavish, B. (2017). Four profiles of inclusive supportive teachers: Perceptions of their status and role in implementing inclusion of students with special needs in general classrooms. Teaching and Teacher Education, 61, 37-46.

Gistituati, N., \& Suyuthie. Management and Supervision Competences of State Elementary School Principals. International Conference on Education Innovation (ICEI 2017). Atlantis Press.

Hopkins, D. (2015). Improving the quality of education for all: A handbook of staff development activities. New York: Routledge.

Naz, A., Khan, W., Daraz, U., Hussain, M., Alam, I., \& Alam, H. (2012). Assessing the Consequential Role of Infrastructural Facilities in Academic Performance of Students in Pakistan. International Journal of Social Sciences \& Education, 3(2).

Ngure, G. N. (2015). Utilization of instructional media for quality training in pre-primary school teacher training colleges in Nairobi County, Kenya(Doctoral dissertation, Kenyatta University).

Ogbuanya, T. C., \& Okoli, S. T. (2014). Workshop equipment and facilities as critical factors for Sustainable Skill Acquisition through TVET in Nigeria. JORIND, 12(2), 323 - 326.

Ogbueghu, S. N., \& Ugwu, I. O. (2016). Junior Secondary Schools Pupils with Disabilities and Their Access to Quality Education. Global Journal of Applied, Management and Social Sciences, 12. 42-49.

Okoye, R., \& Arimonu, M. O. (2016). Technical and Vocational Education in Nigeria: Issues, Challenges and a Way Forward. Journal of Education and Practice, 7(3), 113-118.

Olaitan, S. O. (1996). Vocational education in Nigeria and manpower development. Unpublished Manuscript. University of Nigeria, Nsukka.

PaDelford, H. E. (1984). Acquiring Psychomotor Skills. Journal of Epsilon Pi Tau, 10(2), 35-40.

Galguera, M. P. (2016). The influence of UNESCO on the development of national technical education and vocational training: A comparative study in Botswana and Namibia (Doctoral dissertation, Universidad Autónoma de Madrid).

Saari, H. A., \& Rashid, A. M. (2013). Relationship between implementation of cooperative vocational education and job offering among apprentice of National Dual Training System in Malaysia. Middle-East Journal of Scientific Research, 18(11), 1578-1583.

Seng, N. L., Hanafi, Z., \& Taslikhan, M. B. (2016). Parenting Styles and Academic Achievement. Journal of Arts, Humanities and Social Sciences, 193-200.

Wilder, S. (2014). Effects of parental involvement on academic achievement: A metasynthesis. Educational Review, 66(3), 377-397. 